San Jose State University

SJSU ScholarWorks

Faculty Publications, Anthropology

Anthropology

$1-1-2012$

\title{
Theravada Buddhism and Political Engagement among the Thai- Lao of North East Thailand: The Bun Phra Wet Ceremony
}

Sandra Cate

San Jose State University, sandra.cate@sjsu.edu

Follow this and additional works at: https://scholarworks.sjsu.edu/anth_pub

Part of the Anthropology Commons

\section{Recommended Citation}

Sandra Cate. "Theravada Buddhism and Political Engagement among the Thai-Lao of North East Thailand: The Bun Phra Wet Ceremony" South East Asia Research (2012): 329-342.

This Article is brought to you for free and open access by the Anthropology at SJSU ScholarWorks. It has been accepted for inclusion in Faculty Publications, Anthropology by an authorized administrator of SJSU ScholarWorks. For more information, please contact scholarworks@sjsu.edu. 


\title{
Theravada Buddhism and political engagement among the Thai-Lao of North East Thailand: the Bun Phra Wet ceremony
}

\author{
Leedom Lefferts and Sandra Cate
}

\begin{abstract}
The Thai-Lao of North East Thailand (Isan), the major ethnic group in a core area of the Red Shirt movement, have long expressed concern with the well-being of the muang - now nation-state - in which they reside. This paper explores the proposition that the moral foundations for continuing political engagement at the muang level are explicitly stated in the annual Theravada Buddhist festival, the Bun Phra Wet, celebrated in almost every Thai-Lao village. Moreover, these concerns also involve appropriate actions by the people to correct the systems in which they live.
\end{abstract}

Keywords: political action; moral foundations; Thai-Lao; Theravada Buddhism; Bun Phra Wet; North East Thailand (Isan)

Author details: Leedom Lefferts is Emeritus Professor of Anthropology at Drew University, Madison, NJ. USA. E-mail: Ileffert@drew.edu. Sandra Cate (corresponding author) is a Lecturer in the Department of Anthropology at San José State University, One Washington Square, San José, CA 95192-0113, USA. E-mail: scate@ix.netcom.com.

By November 2010, barely eight months after the Red Shirt occupation of central areas of Bangkok and the police crackdown, scant visible evidence of the conflict remained in Isan areas that had sent many of the Red Shirt demonstrators: no banners or signs, no public memorials, few red shirts for sale in local shops. Leedom Lefferts, one of the authors of this paper, returned to the village where he had conducted research for 40 years, anxious to learn about the Red Shirt movement, its village participants and the events' impacts on their lives. Villagers told him that people did not want to fight one another openly, so the situation was little discussed unless he asked. After he had been in the village for several months, he did attend one decorous Red Shirt rally. Talking to his village friends, he found it easy to collect the names of people who had gone to Bangkok for varying periods during the Ratchaprasong encampment, and he talked extensively to them about what they did there.'

1 Our thanks to our village friends with whom we have lived for several decades. Obviously, the current situation in one village may not be replicated in others. Additionally, the atmosphere of these villages may have changed in the period between the dates of research for this paper and its publication. See, for example, the following articles in The Isaan Record, http://isaanrecord.com, all with no author noted, 'Off the radar', Red villages wait', 16 July 2011 ; 'In Udon, Red villages grow into Red districts', 19 November 2011 ; 'Red village thwarted, a community divided', 11 January 2012; 'News in Brief: 'Red district movement expands into Khon Kaen', 24 January 2012; 'One thousand Red villages open in Isaan', 21 February 2012. Thanks to the Asian Civilisations Museum, Singapore, for providing a research fellowship to Lefferts during the period when this article was completed.

South East Asia Research, 20. 3, pp 329-341 doi: 10.5367/sear.2012.0110 
Most impressive during these discussions, and evident from the people's general behaviour as well as what they were saying, were their expressions of entitlement, or rightfulness, to engage in the Red Shirt protests. Lefferts's friends thought it appropriate to make their dissatisfactions with the government known and they expected the government to respond appropriately to correct these issues. Political change (but not without further trouble) did eventually occur over the months following the demonstrations. Expressing their dissatisfaction with the way Prime Minister Abhisit Vejjajiva and the Democratic Party ran the government, these friends, along with millions of other like-minded voters, resoundingly turned that government out in favour of a politically naïve but powerfully connected novice, Yingluck Shinawatra, sister of deposed Prime Minister Thaksin Shinawatra.

This paper and the questions of political legitimacy it addresses rest on the villagers' belief that it is appropriate for them - middle-class farmers - to voice their grievances and to expect the government to respond. The paper explores ritualized dimensions of the deeply rooted entitlement the Thai-Lao of Isan feel regarding themselves in their relationships with their rulers. The people know they have rights to a voice; they have rights to amend that voice as circumstances require; and these rights come not from capabilities bestowed by someone, but from the fundamentals of their social compact with those who propose to rule over them.

Without holding that these rights wholly come from or are made apparent in any one ritual or item of behaviour - we are not essentialists - we assert that the annual Bun Phra Wet ${ }^{2}$ festival held throughout Isan reflects, refracts, and in its performance activates this sense of entitlement. The Bun Phra Wet, as celebrated by the North East Thai-Lao and, in the Lao PDR, the Lao, commemorates the great merit made by Prince Vessantara, the penultimate incarnation of the karma that will be reborn as Siddhartha Gautama, who becomes the Buddha. North East Thai-Lao and Lao villagers have produced one 'spin' on a story known throughout the Buddhist world as the Vessantara Jåtaka; other cultural systems 'spin' this important, well known story in other ways. ${ }^{3}$ Only the Thai-Lao and the Lao on the left bank of the Mekong emphasize the story of the Vessantara Jataka with the ritualized actions we discuss below. Because we refer to the Red Shirt movement in Thailand, we restrict our generalizations to the Thai-Lao, much the larger population. ${ }^{4}$

This paper also rests on perspectives of local Theravada Buddhism now coming to the fore in Thai and Lao studies. Emerging threads of discourse hold that local Buddhisms have in the past differed and continue at present to differ from the official Buddhism generated by state systems and codified by doctrinal readings

2 In Thai and Lao, 'Wetsandon' is the long form of expression of the Pali 'Vessantara', and Wet (pronounced Wate or Wait) is the shortened form of the Prince's name. In Thai and Lao, 'Prince' becomes the honorific 'Phra'.

3. Naomi Appleton (2010), Jataka Stories in Theravada Buddhism: Narrating the Bodhisatta Path, Ashgate Publishing, Aldershot, and Burlington, VT; Katherine Bowie (2011), 'Regional variation in performances of the Vessantara Jataka in Thailand: a historical perspective', paper presented at $16^{\text {th }}$ Congress, International Association of Buddhist Studies, June, Taiwan; Steven Collins (2008), Nirvana and Other Buddhist Felicities, Cambridge University Press, Cambridge.

4 Our research indicates that similar issues of governance hold in the Lao context, but we do not discuss those here. 
of Buddhist texts. While these statements are not especially new, the literature on local Buddhisms, especially for North East Thailand, may be approaching a critical mass which will enable it to be liberated from the view that it is a pale variant of Central Thai standards. This is becoming especially important as scholars pick apart the so-called hegemonic discourse of what has been regarded as standard Buddhism, proposing a displacement of the centre's authority. ${ }^{5}$

The story of Prince Vessantara Jåtaka is foundational to Thai-Lao and Lao lives and knowledge. Fragments of the story provide references and rejoinders in the oral culture of villagers and city folk. Thai-Lao use the story's characters as models for understanding and judging the behaviour of others. Prince Vessantara figures large in Isan visual culture - scenes of the story appear on wat [temple] walls throughout the region and on the long, painted scrolls villagers use in the Bun Phra Wet. Almost every Thai-Lao and Lao wat community in North East Thailand, Laos and wherever other large groups of Thai-Lao or Lao live and control their ritual calendar, such as the Thai Central Plains and in the Lao diaspora, celebrates the Bun Phra Wet in the third or fourth month of the traditional lunar calendar (mid-February through mid-April).

We do not recount the complete story; it is widely available in the vernacular in both North East Thailand and Laos. While English-language translations of these vernacular texts do not exist, scholars have made detailed translations from Pali versions, often conceptualizing the Prince Vessantara narrative as the search for 'perfect generosity', one of the virtues that the Buddha-to-be perfected along his path to Enlightenment. ${ }^{6}$ In any case, the story as written text is not the most important genre by which Thai-Lao and Lao know the story. As with any other enduring work of literature, the Vessantara Jataka is subject to a multitude of interpretations as well as modes of telling or performance. ${ }^{7}$ Coding the story as a tale of 'perfect generosity' ignores other complex interpretations.

While the story concerns the actions of a prince destined to be reborn as the Buddha, the Thai-Lao version emphasizes the royals, the Prince and his family as recognizably human people living their lives as best they can, with the separations

5 See Paul Lévy (1957), Buddhism: A 'Mystery Religion'? Athlone Press, London; Kate Crosby (2000), 'Tantric Theravāda: a bibliographic essay on the writings of François Bizot and others on the yogāvacara tradition', Contemporary Buddhism, Vol 1, pp 141-198; Stanley J. Tambiah (1970), Buddhism and the Spirit Cults in North-East Thailand, Cambridge University Press, Cambridge; Yukio Hayashi (2003), Practical Buddhism among the Thai-Lao: Religion in the Making of a Region, Kyoto University Press, Kyoto; James L. Taylor (1993), Forest Monks and the NationState: An Anthropological and Historical Study in Northeastern Thailand, Institute of Southeast Asian Studies, Singapore; Kamala Tiyavanich (1997), Forest Recollections: Wandering Monks in Twentieth-Century Thailand, University of Hawaii Press, Honolulu, HI; Justin T. McDaniel (2008), Gathering Leaves and Lifting Words: Histories of Buddhist Monastic Education in Laos and Thailand, Silkworm Books, Chiang Mai, and (2011), The Lovelorn Ghost and the Magical Monk: Practicing Buddhism in Modern Thailand, Columbia University Press, New York; Leedom Lefferts and Sandra Cate. (2012), Buddhist Storytelling: The Vessantara Jataka Scroll at the Asian Civilisations Museum, Asian Civilisations Museum, Singapore.

6 For translations from the Pali, see Margaret Cone and Richard F. Gombrich (2010), The Perfect Generosity of Prince Vessantara: A Buddhist Epic, The Pali Text Society, Bristol; and E.B. Cowell and W.H.D. Rouse, translators (1907), The Jataka, Vol VI, at http://www.sacred-texts.com/bud/ j6/j6013.htm (accessed 6 March 2012). An English translation by John Crocker of a Thai-language summary is available online at: https://digitalcollections.anu.edu.au/html/1885/41898/ wetsandon.html (accessed 20 February 2012).

7 Steven Collins (2012), 'Introduction and list of dramatis personae', in Readings of the Vessantara Jåtaka (forthcoming), Columbia University Press, New York. 
and reunions, joys and tribulations that Thai-Lao (if not all humanity) experience as members of families. The story offers both existential and emotional drama; set in the past, in an era even before the Buddha was born as Siddhartha Gautama, it provides elements for enactment relevant in the present. In the Bun Phra Wet, Thai-Lao actively perform roles in the story, even if only as members of the supporting cast. Further, their engagement with material objects during the festival and the emphasis they give to negotiating the return of the Prince to his Kingdom establish the Thai-Lao not only as active storytellers, but as political agents. Past scholarship on the Bun Phra Wet focuses on the festival's last-day recitation of the Vessantara Jåtaka as a means of forming moral subjectivities and furthering soteriological goals; we argue instead for a more holistic account of the entire festival. ${ }^{8}$ Thus, we present here a synopsis of the story focusing more on how Thai-Lao perform it to make statements about the relations of ruler and ruled, of their demand to be heard and the redress of their grievances.

\section{A political synopsis of the Vessantara Jåtaka story}

It was prophesied to his father that Prince Vessantara would be born as someone 'being devoted to almsgiving' and whenever asked, would give away any item that he possessed. ${ }^{9}$ At the beginning of the story, he has assumed the Kingship, his father (King Sonchai of Sivi) having abdicated in his name. ${ }^{10}$ From the time of his birth, as a result of his mother Queen Phutsadi's wish concerning her own rebirth in the human world, he is impelled to give. He gives when he is born and he gives again and again throughout his youthful life.

However, as he matures and after he becomes king, Phra Wet makes the first major gift of an object that is not his personal property, the gift that alienates him from his citizens. When asked by eight Brahmins from the adjoining Kingdom of Kalinga, which has been suffering from drought for seven years, seven days, seven hours, seven minutes and (as monk reciters of the story sometimes say), seven

× See Anuman Rajadhon, Phraya (1986), 'Sacred recitation', in Popular Buddhism in Siam and Other Essays, Thai Inter-Religious Commission for Development, Sathirakosis Nagapradica Foundation, Bangkok; Bonnie Pacala Brereton (1995), Thai Tellings of Phra Malai: Texts and Rituals Concerning a Popular Buddhist Saint, Program for Southeast Asian Studies, Arizona State University, Tempe, AZ; Collins, supra note 3; Georges Condominas (1998), Le Bouddhisme au village: notes ethnographiques sur les pratiques religieuses dans la société rural lao (plaine de Vientiane), Editions des Cahiers de France, Vientiane; Cone and Gombrich, supra note 6; Bernard Formoso (1992), 'Le Bun Pha Wet des Lao du Nord-est de la Thailande', BEFEO, Vol 79, pp 233-260; William J. Klausner (originally published 1966, reprinted 1993), 'Ceremonies and festivals in a Northeastern Thai village', in Reflections on Thai Culture, The Siam Society, Bangkok, and (2000), Reflections: One Year in an Isaan Village Circa 1955, Siam Reflections Publications Co Ltd, Bangkok; Stephen Sparkes (2005), Spirits and Souls: Gender and Cosmology in an Isan Village in Northeast Thailand, White Lotus, Bangkok; Melford Spiro (1970), Buddhism and Society: A Great Tradition and its Burmese Vicissitudes, University of California Press, Berkeley, CA; Suriya Smutkupt, Pattana Kitiasa, Kanokpon Diiburii, Sathapon Undaeng, and Priichaa Sriichai (2543/ 2000), Kaan Muang Watthanathaam nay Bun Phawet Roi-et [Cultural Politics and the Secularization of the Bun Phawet in Roi-et], Office of Social Technology Studies, Suranarii Technology University, Nakhon Ratchasima; Tambiah, supra note 5; Patrice Ladwig (2009), 'Narrative ethics: the excess of giving and moral ambiguity in the Lao Vessantara-Jataka', in Heintz, M., and Rasanayagam, J., eds, The Anthropology of Moralities, Berghahn/EASA, New York, pp 136-155.

9 Cowell and Rouse, supra note 6.

10 As this essay concerns the narrative as told in Isan, we use Thai-English transliterations of the characters' names. 
seconds, and seven wi-wa [sic, possibly nano-seconds], he gives away the Kingdom's white elephant that guarantees rain - and thus prosperity - and that symbolizes the Kingdom. Angered, the citizens of Sivi send their representatives to his father, the former king, to request that something be done.

When we ask Isan monks and laity about this section of the story, their answers are clear: the citizens ask their representatives to convey their demands to a 'court of last resort', the father of King Vessantara, and Sonchai accedes. These monks and laity call this prachathipithai [democracy]. In the context of contemporary political events in Thailand, they clearly refer here to their rights to be consulted and state that their interests are to be taken into account."

In the Vessantara Jåtaka, Sonchai, afraid that the people will ask that his son be killed, suggests that he should be banished to Crooked Mountain in the Himalayas. The citizens agree. However, Vessantara takes an extra day. He mobilizes the Kingdom's wealth and proceeds to give that away to all who ask. This 'gift of the 700 s' puzzles them; they now begin to realize that their King has guaranteed prosperity to them, as, through his generosity, increasing numbers of gifts have brought about increased wealth among the citizens. However, with his imminent departure, even the beggars, recipients of his largesse, roll in the streets, wailing, 'Who will support us now that Vessantara has given everything away?'12

Vessantara goes into exile; his wife and children go with him out of love. Once the family leaves the Kingdom of Sivi, the gift-giving aspects of the story focus on Prince Vessantara donating that which he personally owns and the merit accrued through those gifts. At first, to the Brahmins requesting them, he gives the horses pulling the chariot that carries the family, then the chariot itself. The family walks to the forest, assisted by the gods who miraculously shorten the journey. Once ensconced at the Crooked Mountain hermitage, Vessantara's only possible remaining gifts are his family members; these he gives to questing Brahmins; as he does so, he calls them 'golden ships', 'steady boat(s) on the sea of becoming'. ${ }^{13}$

Vessantara's donations take place at the forest hermitage; they do not involve the Kingdom's citizens. The rest of the world - kingdom, parents and citizens re-enter the story when Chuchok, the Brahmin with the donated children, stumbles, lost, out of the forest into the Kingdom of Sivi, where their grandfather reigns. A border guard recognizes the children and orders the trio to the palace. Their grandfather ransoms his grandchildren, giving the Brahmin so much wealth that he greedily overeats (the opposite of Vessantara's generosity) and self-destructs as his stomach bursts.

The king resolves to bring his son and daughter-in-law back from Crooked Mountain; he orders his generals to build a wide road and organize the army to make the trip; the people accompany the procession. As the entourage reaches the couple at the hermitage, everyone swoons from the joy of reunion, and the King

"See the special issue of the Journal of Contemporary Asia, Vol 38, No 1 (2008) for essays considering implications of the 2006 coup for democracy in Thailand.

12 Cone and Gombrich, supra note 6, at $\mathrm{p} 21$. This ambiguity in the citizens' response to Vessantara's generosity has been inadequately explored. On the one hand, the citizens depend on his generosity to support the Kingdom's increasing wealth as well as its 'social welfare' programmes. On the other, they deeply regret his donation of the elephant and the last gesture of support implicit in the Gift of the 700s. See Cone and Gombrich, supra note 6, at pp xix-xx.

13 Lefferts and Cate, supra note 5, at p 127; Cone and Gombrich, supra note 6, at p 58. 
of the Gods releases a blessed ruby-red rain to revive them. After recovering, the citizens' representatives approach Vessantara and exhort him to return from exile to resume his Kingship. He has prepared for this, having earlier asked the King of the Gods to grant him eight wishes, one of which was that he should return to the city and take his rightful seat. An inscription on the painted scroll at the Asian Civilisations Museum in Singapore has this request as 'May I return to (my) city'. ${ }^{14}$ At the hermitage, the representatives approach and, making an offering to Vessantara, say, in another of this scroll's many captions, 'Please return to your city to be our lord and ruler - to build halls and castles'. This represents to them a return to prosperity. ${ }^{15}$

A joyful month ensues as the procession returns to the Kingdom with the six royals (father, mother, Vessantara, his wife and their two children) riding elephants, the army marching and the citizens celebrating, festivities all the way.

\section{Enacting the Bun Phra Wet}

As 'strategic practice', members of Thai-Lao communities perform these salient points of the story during the annual Bun Phra Wet, expressing their relationship to the monarchy and their roles in the Thai political system. ${ }^{16}$ They do so primarily through an artefact unique in mainland South East Asian material culture: long, painted cotton scrolls, usually $30-40$ metres by one metre wide. Painted on these scrolls are the 13 chapters of the Vessantara Jataka in varying detail, ${ }^{17}$ plus additional panels that place the story in its Buddhist context. Thousands of these long, painted scrolls probably exist. Almost every village wat and many urban temples in North East Thailand have at least one. The differences between the Thai-Lao Bun Phra Wet performances and recitations of the Vessantara Jåtaka that predominate in other areas of Theravada Buddhist South East Asia pivot around this scroll, its visual and material qualities, and how the Thai-Lao use it. ${ }^{18}$

On the afternoon of the festival's first day, villagers take the furled scroll, a small offering plate and other objects and travel to a place they have designated the paa, or forest. There they perform the ceremony soen Phra Wet khao nai muang, asking Phra Wet to return to his kingdom. Before leaving their homes, they decorated the wat and their village as a muang, a royal centre, with thousands of items signifying the wealth and presence of royalty: 1,000 betel nut chews, 1,000 packages of cigarette tobacco, 1,000 small flags, etc. ${ }^{19}$ Other symbols of royalty - fly

14 ACM accession \# 1997-2933.

15 Translation and contextualization courtesy of Dr Wajuppa Tossa.

16 We are here following the theory of ritual proposed by Catherine Bell (1992, reissued 2009), Ritual Theory, Ritual Practice, Oxford University Press, Oxford. Working with Bourdieu, Gramsci and other theorists of social action, she holds that ritual asserts a 'vision of empowerment...rooted in the actor's perceptions and experiences of the organization of power' ( $p$ 85).

17 Some 20-30 and more years ago, scrolls were usually produced by village artists and sold or traded within an area. Now, two Isan villages specialize in their production; thus, unfortunately, scrolls in general use today are becoming standardized.

is A close reading of one very important Vessantara scroll with comparisons to other scrolls is available in Lefferts and Cate, supra note 5.

19) ' 1000 ' has become standardized as the number of verses in the textual versions of the Jataka. But see Claudio Cicuzza, and Peter Skilling (2010), 'The number of stanzas in the Vessantara jâtaka: preliminary observations', in Giacomella Orofino and Silvio Vita, eds, Buddhist Asia 2: Papers from the Second Conference of Buddhist Studies held in Naples in June 2004, Italian School of East Asian Studies, Kyoto, pp 35-45. 


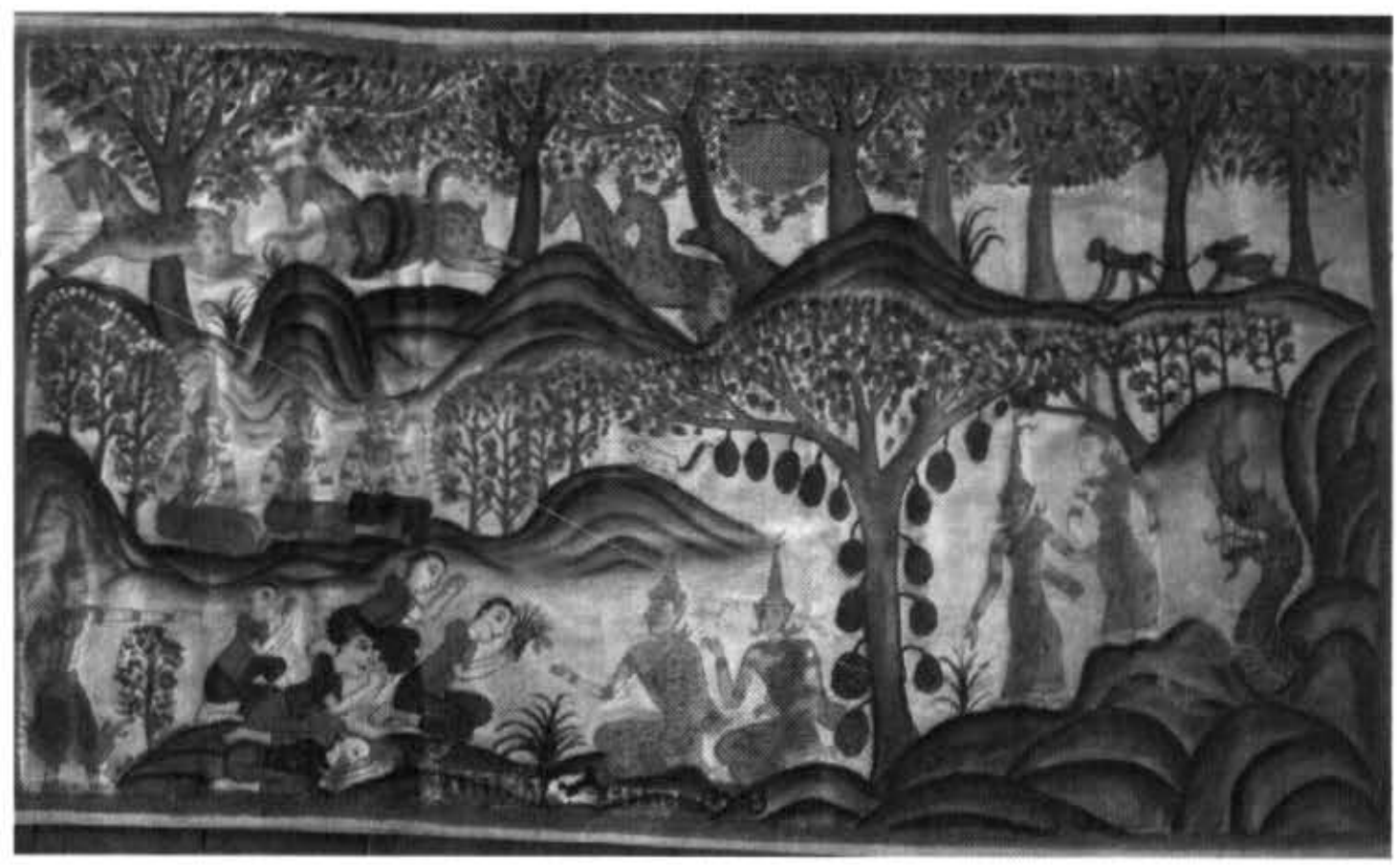

Figure 1. People's representatives ask for Phra Wet to return to the muang. Detail from scroll dated 1963, Udon Thani province.

Photo (1) the authors.

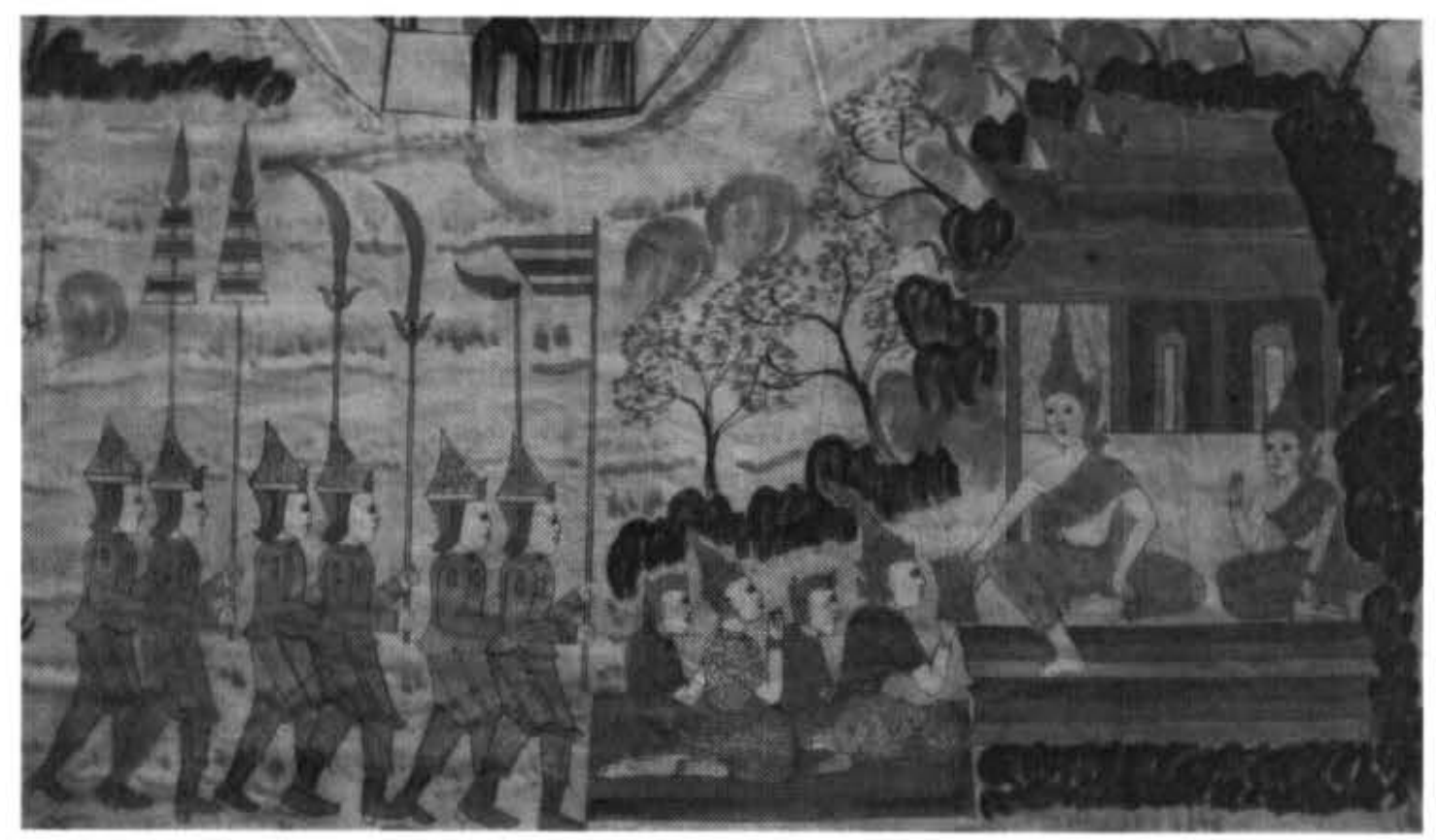

Figure 2. King Sonchai presents offerings to Phra Wet, asking for him to return to the Kingdom. Detail from scroll dated 2006. Ubon Ratchathani province.

Photo (1) the authors. 
whisks, seven-tiered umbrellas and royal flags - surround the meeting hall. Thus, when the villagers bring Phra Wet back to their homes, they bring him and his family back to a muang, with all the implications of that term, which serve to elevate the stature of their village. ${ }^{20}$

Depictions on the scrolls and enacted re-creations differ from community to community; the soen Phra Wet is not uniform across North East Thailand. The written and recited texts do not always make clear who asks Vessantara to return and how he responds. These issues occur in the depiction of Chapter Twelve, Chokasat, 'Six royals'. Current Isan storytellers, the monks who read or recite the story, have various versions.

Several monk informants stated that the people's representative invited Vessantara and he accepted. When asked why a layman, and not the Prince's father, would ask Vessantara to return, monks responded that it would be inappropriate for a man's father to wai [bow] before his son, a younger man. In many scrolls a nonroyal, the people's representative, is depicted presenting the offering to Vessantara (see Figure 1).

In another version, other laity and monks said that age and status did not matter; the King ordered Vessantara to leave, so the King had to invite Vessantara to return. This is also depicted on other scrolls (see Figure 2).

In still another version - not yet seen on any scroll, but enacted in a number of ceremonies in which monks and laity both participate in extending the invitation - the King (a villager acting as Sonchai) twice asks Vessantara to return and he refuses, even turning his back on his father as he rejects his entreaty. However, on the third attempt, in desperation, a representative of the people asks. Only then does Vessantara turn around to face this representative and accept the offering from a designated villager/citizen, acknowledging his willingness to return to govern the Kingdom.

Finally, in yet another variation, seen only in Ubon Ratchathani province, it takes more than men to induce Vessantara to return. The people stage this as follows: first, their representative asks and Vessantara refuses. Second, King Sonchai, Vessantara's father, requests that the Prince return; Vessantara turns his back on him. Third and finally, his mother, Queen Phutsadi, asks and, because Vessantara is her son, he cannot refuse. Of course, this telling of the story fits with yet another narrative embedded in the jåtaka concerning the disintegration and reconstitution of families, as well as expressing Thai-Lao notions of a son's obligations towards his mother and her sacrifices in raising him. ${ }^{21}$

Note that, regardless of which version of the request a community has adopted, the citizens of that community are full participants in the story's re-enactment. The celebrants of today's Bun Phra Wet become the citizens of the story. The

21) Richard A. O'Connor (1990), 'Siamese Tai in Tai context: the impact of a ruling center', Crossroads, Vol 5, pp 1-21; Hayashi, supra note 5; Leedom Lefferts (1975), 'The historical demography of developing areas: a theoretical and research frontier', in J.S. Williams, A.M. Schwartzbaum, and R.F. Ganey, eds, Sociological Research Symposium V, Virginia Commonwealth University, Richmond, VA, pp 64-69; Leedom Lefferts (1977), 'Frontier demography: an introduction', in D.H. Miller, and J.O. Steffen, eds, The Frontier: Comparative Studies, University of Oklahoma Press, Norman, OK, pp 33-55.

21 Leedom Lefferts (1994), "Clothing the serpent: transformations of the Naak in Thai-Lao Theravada Buddhism', in L. Milgram, and P. Van Esterik, eds, The Transformative Power of Cloth in Southeast Asia, Canadian Council for Southeast Asian Studies, Montreal, and Museum for Textiles, Toronto, pp 19-38. 
people and monks stand and unroll the scroll with the jaitaka painted on it. Then, as if the scroll were a long string, a sai sin or sacred thread connecting them with the merit they are amassing, they carry it for one to two kilometres from the paa [forest] through fields, then through the village that has now become the muang, to the wat, where it is hung. ${ }^{22}$ As the procession goes through the village, it collects more celebrants, who either help carry the scroll's weight, or joyfully dance at the procession's rear, usually to deafening music. Villagers, when asked, say that they are taking Phra Wet to the muang; some have said the cloth carries the 'spirit of the Prince'.

On scrolls, this processional scene in Chapter Thirteen, Nakhon ('A grand muang'), is often the longest, sometimes taking 20-30\% of the total scroll length. As this chapter is one of the shortest scenes in written texts, it is obviously important to the people of this region. The procession and festivities painted on the Nakhon section of the scroll and enacted in their performance represent their success in acquiring a ruler with whom they can agree, at the same time as they celebrate the transformation of their community from a baan nork [outback village] to a mighty muang, the most important that day. Moreover, the transformation of the baan to a muang makes clear that the citizens of this place are siwilai [civilized], rather than backward, upcountry hicks, as Isaners are often represented in central Thai popular culture. ${ }^{2.3}$

The procession returning to the wat also anticipates a return to prosperity and the citizens' future successes, along with those attained by the Prince.

While scrolls often include depictions of contemporaneous elements, it is rare to see particular identifiable individuals. An exception is one scroll found in a Central Thai wat, thought to have been painted in Isan, in which King Bhumiphol Adulyadej is depicted as a leading member of Vessantara's returning entourage. This is the only time we have seen a direct connection drawn between the Thai monarchy and the Bun Phra Wet on the scrolls, although on some scrolls, soldiers in the procession carry Thai flags and Thai flags are often displayed as part of the overall decorative scheme for the festival.

We learn at the end of the story, as recited by the Buddha, that the associates of Phra Wet are also the Buddha's associates; they are reborn to be together in this (Siddhartha's) life. The merit that the people make encourages them to believe that their lives will be more meritorious and, possibly, may assure them rebirth in the same collective at the time of the next Buddha-to-come, Phra Sri Ariya Maitreya.

This performance takes place the day before the recitation. In other, non-Isan

22 Note the dialectical complementarity between forest and muang posited by these actions and the position of the baan [village] between them. We treat this subject in other works on the Bun Phra Wet: Leedom Lefferts and Sandra Cate (2012), 'Constructing multiple narratives in Theravada Buddhism: the Vessantara painted scrolls of Northeast Thailand and lowland Laos', in A. Green, ed, Rethinking Visual Narratives from A sia: Intercultural and Comparative Perspectives (forthcoming), Hong Kong University Press, Hong Kong; Sandra Cate and Leedom Lefferts (2012), 'Becoming active/active becoming: Prince Vessantara scrolls and the creation of a moral community', in J. Bautista, ed. The Spirit of Things: Materiality in the Age of Religious Diversity in Southeast Asia (forthcoming), Cornell Southeast East Asia Program Publications Press, Ithaca, NY.

2.3 For a discussion of siwilai and the processes by which Isan and its people came to oppose the 'modern' status of the Bangkok elite, see Thongchai Winichakul (2000), 'The others within: travel and ethno-spatial differentiation of Siamese subjects 1885-1910', in A. Turton, ed, Civility and Savagery: Social Identity in Tai States, Curzon, Richmond, pp 38-62. 
contexts, listening to the recitation and the perfection of generosity seem to be the main points of the story. Among Isaners, the numbers of people listening to the story's recitation are usually substantially fewer than those participating in the soen Phra Wet and the resulting procession and festivities. Thus, the transformation of the story by the Thai-Lao, during which they add this active component, codifying their relationship with their rulers and declaring that they are proper Tai with all the rights of a muang, is integral to their sense of the story's meanings.

The central point of the Thai-Lao enactment of the story is precisely to raise and settle the issue of the relationship between ruler and ruled and the consequences for the people's merit and welfare. The tension embodied in the citizens' initial response to Vessantara's seemingly wilful neglect of their interests by donating the elephant, leads, as they quickly discover, to even more gifts. This results in their realization that his exile may not be in their own best interests. Remember the wailing that occurred as Vessantara made the gift of the 700s. As they wail, the people recognize that the Prince, though he has given so much away, has still guaranteed the Kingdom's prosperity.

\section{Marginality and the Bun Phra Wet}

The Isan celebration of the Bun Phra Wet poses a paradox. The use of the Vessantara Jătaka as a mythic model for the Thai and Lao phu mii bun movements of the late nineteenth century is well documented. ${ }^{24}$ In response to these millenarian movements, the court sought to suppress the Vessantara Jataka, seen as threatening the authority of the central monarchy. Patrick Jory notes,

'It (wa)s....in the Thai court's political agenda (under King Chulalongkorn) of strengthening its hold over the kingdom's hinterland, that the real reason for the official marginalization of the Jatakas in the Thai Buddhist tradition can be found' .25

But the jatakas, especially the Vessantara Jåtaka and its annual performance in the Bun Phra Wet, are alive and well in what has long been regarded (by the Bangkok-based national elite) as one of the most marginalized areas of the country.

How can we explain this? Since Charles Keyes's definitive Isan: Regionalism in Northeastern Thailand appeared in 1967, the study of Thai and South East Asian regions has analysed issues of centres and peripheries, borderlands, fuzzy boundaries, galactic polities, marginality, and more, providing a larger context for our discussion of the Bun Phra Wet. ${ }^{26}$ At the same time, recent studies of Thai

24 Charles F. Keyes (1977), 'Millennialism, Theravada Buddhism, and Thai society', Journal of Asian Studies, Vol 36, No 2, pp 283-302; Yoneo Ishii (1975), 'A note on Buddhistic millenarian revolts in Northeastern Siam', Journal of Southeast Asian Studies, Vol 6, No 2, pp 121-126.

25 Patrick Jory (2002), 'Thai and Western Buddhist scholarship in the age of colonialism: King Chulalongkorn redefines the Jatakas', Journal of Asian Studies, Vol 61, No 3, pp 891-918.

${ }_{20}$ See Charles F. Keyes (1967), Isan: Regionalism in Northeastern Thailand, Data Paper No 65, Southeast Asia Program, Department of Asian Studies, Cornell University, Ithaca, NY; Tambiah, supra note 5; James Scott (2009), The Art of Not Being Governed: An Anarchist History of Up. land Southeast Asia, Yale Press, New Haven, CT; Anna Lowenhaupt Tsing (1993), In the Realm of the Diamond Queen: Marginality in an Out-Of-The-Way Place, Princeton University Press, Princeton, NJ; O.W. Wolters (2009), History, Culture, and Region in Southeast Asian Perspectives, revised ed, Cornell University Southeast Asian Studies, Ithaca, NY. 
historiography have shed increasing light on the dynamics of the central state of which Isan is a part and aspects of Isan's 'regional' status, thus giving us a more comprehensive understanding of the contexts in which Isan regionalism operates. ${ }^{27}$

These studies have contributed to a scholarly awareness, as Nicolas Tapp wrote and David Streckfuss charts, of 'the extraordinary diversity of cultural identity (and "multiple histories", Streckfuss adds) which the modern nation-state of Thailand has controlled, and which it has largely been able successfully to disguise' ${ }^{28}$

McCargo and Krisadawan ${ }^{29}$ review popular representations - by both insiders and outsiders - of Isaners 'as a marginalised and disadvantaged group'. Even though the Isan population comprises over one-third of the Kingdom's population, and the Khorat Plateau, which houses Isan, comprises one-third of its land area (more people and more land area than any other "ethnoregional' ${ }^{30}$ group in Thailand, including the Central Thai), its people are consistently depicted as less refined in the Central Thai-dominated system. ${ }^{31}$

But 'regional' may not necessarily mean deprived or always less fortunate than those better privileged people in the centre. In discussing state power in Chad, central Africa, Janet Roitman ${ }^{32}$ notes 'margins are not wastelands of emulation, but places where production occurs' ${ }^{33}$ New cultural forms produced in the margins are not simply more primitive or less elaborated versions of what occurs in the centre. Ashley, citing Tsing, ${ }^{34}$

'reminds us, however, (that) marginalization is....a process that people may work to counter. In this regard, de-marginalization (the processes which challenge the power of the centre to marginalize its "other") is important for understanding the particular religious discourses and practices that emerge amongst marginalized people, phenomena which often make claims to greater

27 See, for example, Thongchai Winichakul (1994), Siam Mapped: A History of the Geo-body of a Nation, University of Hawaii Press, Honolulu, HI; Craig J. Reynolds and Team (2011), Time's Arrow and the Burden of the Past: A Primer on the Thai Un-state, website: http://anu.academia.edu/ CraigReynolds/Papers/924979/Times_Arrow_and_the_Burden_of_the_Past_A_Primer_on_the _Thai_Un-state (accessed 6 March 2012).

2* Many sources have challenged the master narrative of Thai historiography; these two sources provide entry into this material: Nicolas Tapp (2000), 'A new stage in Tai regional studies: the challenge of local histories', in A. Turton, ed, Civility and Savagery: Social Identity in Tai States, Curzon, Richmond, pp 351-359; David Streckfuss (2012), "An "ethnic" reading of "Thai" history in the twilight of the century-old Thai national model', printed in this issue, pp 305-327. But see Kennon Breazeale (1975), 'The integration of the Lao states into the Thai Kingdom', PhD dissertation, Oriental Studies, Oxford University, which exposed these issues at an early date.

29 Duncan McCargo and Krisadawan Hongladarom (2004), 'Contesting Isan-ness: discourses of politics and identity in Northeast Thailand', Asian Ethnicity, Vol 5, No 2, pp 219-234.

30) Keyes supra note 26, at pp 213-216.

3 See Terry Miller (2005), "From country hick to rural hip: a new identity through music for Northeast Thailand', Asian Music, Vol 36, No 2, pp 96-106; James Mitchell (2009), 'Sorapet Pinyoo and the status of pleeng luuk tung', Journal of Southeast Asian Studies, Vol 40, No 2, pp 295-321; Leedom Lefferts (2005), 'Sticky rice, fermented fish, and the course of a kingdom: the politics of food in Northeast Thailand', Asian Studies Review, Vol 29, pp 237-248.

32 Janet Roitman (2004), 'Productivity in the margins: the reconstitution of state power in the Chad Basin', in Veena Das and Deborah Poole, eds, Anthropology in the Margins of the State, School of American Research, Santa Fe, NM, pp 212-213.

3.3 Sean Ashley (2011), 'Late for Buddha: the construction of Dara'ang (Silver Palaung) religious and ethnic identity', PhD dissertation, Anthropology, Simon Fraser University, Vancouver, BC, p 14.

34 Tsing, supra note 26 , at $\mathrm{p} 13$. 
authenticity and piety, or in the case of millenarian movements, the revelation of a local holy person. ${ }^{35}$

Two case studies that have just been published discuss productivity and demarginalization at the margins of the Thai Kingdom: Mikael Gravers's study of royal imaginary among the Karen of western Thailand ${ }^{36}$ and Sean Ashley's work among the Dara'ang (Palaung) in North Thailand. ${ }^{37}$ Both show that the response of marginalized peoples can be constructive and 'centring', creatively coping with situations in which they are continually subjected to exclusion and denigration. The Thai-Lao and Lao Bun Phra Wet ceremony and the relationships between ruler and ruled painted on the scroll and enacted in their performances also represent the centred behaviour of marginalized people and directly challenge (in ritual and political action) constructions of their place in Thai society that would deny them a voice.

\section{Conclusion}

Isaners make the Bun Phra Wet important as a ritualized, strategic practice that responds to their subaltern role in the Siamese/Thai Kingdom. In an earlier paper, ${ }^{38}$ we showed that the Bun Phra Wet was not in and of the past, but today, it provides an ongoing, multi-modal response to continuing marginalization. The millennial statements in the Bun Phra Wet, acted out by the people, make manifest their aspirations within the Thai state. The festival creates an imaginary, a way for Isaners to conceptualize a political system in which they fully participate.

One dimension of this response is how Isaners view themselves as Theravada Buddhists. Through their actions in the Bun Phra Wet, North Easterners establish that they are Vessantara's associates because they are members of the group of people who invite him to return to his muang. Further, they prepare themselves for the arrival of the next Buddha, Phra Sri Ariya Maitreya. There could hardly be a closer association between a people and their soteriological goals.

A second dimension of the response to marginalization is contained in the Isan engagement with the structural distinction of muang, a place of civility, with paa, the forest that represents wildness and danger. By establishing their community as a muang, even if only for a day, they give voice to their aspirations for recognition as civilized people. In this, Isaners participate in a thoroughly Tai, enduring political statement.

Isaners' third dimension is contained in the people's actions regarding kingship during the Bun Phra Wet. Each year, people from almost every Isan community enter the forest and ask their rulers to return, re-negotiating their relationship with their rulers and actively legitimating the rulers' rights and responsibilities to them.

$35 \quad$ Ashley, supra note 33 , at p 14.

36 Mikael Gravers (2012), "Waiting for a righteous ruler - Karen royal imaginary in Thailand and Burma', Journal of Southeast Asian Studies, Vol 43, No 2, pp 340-362.

37 Sean Ashley (2012), 'Charisma in the margins of the state: Dara' ang Buddhism and the Khruba holy men of Northern Thailand', Anthropologica, Vol 54, No 1.

38 Leedom Lefferts, and Sandra Cate (2010), 'The 'routinization of millennialism': impacts of colonialism on the ethnic Lao Festival of the Observance of the Life of Prince Vessantara', paper delivered at the Conference on Theravada Buddhism under Colonialism: Adaptation and Response, May, Nalanda-Sriwijaya Centre, Institute of Southeast Asian Studies, Singapore. 
Finally, a fourth dimension of the response is contained in the Red Shirt movement. This essay has established the clear presence in North East Thailand of a strong imaginary that includes citizens' decision-making powers concerning rulers. Current performances of the Bun Phra Wet lack any indication of a phu mii bun messianic cult on the horizon. North East Thai-Lao culture, through its Buddhist practices, embodies active participation and democratic forms that must be reckoned with. The Red Shirt movement demonstrates this as well.

As a source of raw materials, labour and the production of goods, North East Thailand may no longer be at the margins of the corporate capitalist world; Isan may indeed, as noted by Sirijit Sunanta, become cosmopolitan without having to participate in the Bangkok 'centre'. ${ }^{39}$ From the vantage point of Bangkok, the Thai-Lao may still be located at the cultural margins of the Siamese/Thai state. But, ritually through the Bun Phra Wet and politically through the Red Shirt movement and the power of their collective vote, the Thai-Lao continue to assert their place and their rights.

39) Sirijit Sunanta (2009), 'Global wife, local daughter: gender, family, and nation in transnational marriages in Northeast Thailand', PhD dissertation, University of British Columbia, Vancouver. 